\title{
Towards a Cognitive Theory of Blessing : Dead Sea Scrolls as Test Case
}

\author{
Jokiranta, Jutta Maria \\ de Gruyter \\ 2017
}

Jokiranta , J M 2017 , Towards a Cognitive Theory of Blessing : Dead Sea Scrolls as Test Case . in M S Pajunen \& J Penner (eds), Functions of Psalms and Prayers in the Late Second Temple Period. Beihefte zur Zeitschrift für die alttestamentliche Wissenschaft, no. 486 , de Gruyter , Berlin , pp. 25-47 . https://doi.org/10.1515/9783110449266-003

http://hdl.handle.net/10138/305679

https://doi.org/10.1515/9783110449266-003

cc_by

acceptedVersion

Downloaded from Helda, University of Helsinki institutional repository.

This is an electronic reprint of the original article.

This reprint may differ from the original in pagination and typographic detail.

Please cite the original version. 
Towards a Cognitive Theory of Blessing: The Dead Sea Scrolls as a Test Case

Jutta Jokiranta

University of Helsinki

\section{Introduction}

Blessings consist of words that carry power. The Hebrew root brk ברך) is especially intriguing for the study of blessing because it denotes two different yet related actions: it is used for both praising God and for mediating God's favor to humans. What does this mean for the cognitive perception of the blessing? How does the human mind employ, process, and use the idea of blessing? What intuitions does the mind rely on, and what cultural variables can be identified? The act of blessing also involves more than words. What kind of power does the human mind attach to blessing?

This contribution focuses on some of the insights gained from the cognitive sciences to advance our understanding of blessing as behavior. Cognition is basically anything in the human body and nervous system that helps us get along in the world - to process the perceptual information around us, to move purposefully, to predict and anticipate events, to communicate with fellow humans, to select relevant information from an infinite amount of data around us. The study of blessings is often about semantics and linguistic use, and this is especially true of historical study where the only major sources are textual and the preserved words and phrases lend themselves to analysis. But here I am interested in the underlying belief structures that these concepts are based on and might trigger and in blessings as ritual acts in ritual contexts, even though any in-depth description of ritual acts through the extant textual sources is not possible.

For any historical study of blessings to be useful and structured, it is important to be clear about the levels of analysis in which blessings can be discussed. Since at least some types of blessing can be categorized as prayer, Armin Geertz's more general theory of prayer as communication and as behavior might help us as a starting point to specify the different levels of blessing. ${ }^{1}$ Geertz first distinguishes three levels of analysis when prayer is considered as an act of communication. In terms of his taxonomy, blessing can be analyzed in terms of: (1) the words of blessings themselves; (2) the act of blessing and its performance; and (3) blessing as a subject of discussion with a specific tradition (that is, how blessing is spoken of, instructed, and prescribed). Geertz then continues with prayer as

\footnotetext{
${ }^{1}$ Armin W. Geertz, “Comparing Prayer: On Science, Universals, and the Human Condition,” in Introducing Religion: Essays in Honor of Jonathan Z. Smith, ed. Willi Braun and Russell T. McCutcheon (London: Equinox, 2008), 113-139.
} 
behavior. From this perspective, blessing can be analyzed as: (1) social behavior-bodily movements within time and space, and other contextual conditions; institutional and power relations are also important to consider; (2) psychological behavior - the mental and psychological states and effects the act of blessing produces on these faculties; and (3) neurobiological behavior-neural activity and stimulation in connection to blessing behaviors. ${ }^{2}$ An analysis of these different levels does not mean that the levels could not be connected with each other and shown to influence each other. Rather, having analytical tools that provide answers to distinct questions is the precondition for comparative work, and analytical comparison is a way to understanding. I will first briefly discuss blessing in terms of communication and then introduce a discussion on the cognitive perspectives of magic that are needed to study blessing in terms of behavior, especially at the social and psychological (cognitive) level. In the final section, I will compare some blessing texts among the Dead Sea Scrolls in light of these perspectives.

\section{Blessing is Communication: Semantics and Speech Acts}

In religious studies context, three basic components of blessing are often discussed: consecration (understanding something or someone as empowered to bring benefits), benediction (bestowing good will or favor on someone), and eulogy (glorifying, approving, granting of favor, and aspiring towards good). ${ }^{3}$ To unpack the phenomenon of blessing further, the uses of the Hebrew root $b r k$ are primarily divided into three categories when we consider to whom the blessing is addressed and by whom: humans blessing other humans (or pronouncing objects as blessed), God blessing humans and things, and humans (and/or angels and natural objects) blessing God. According to James Aitken, when both the subject and object are humans, brk denotes "the expressing of the favour conferred on the person by God." When God is the subject, brk denotes "[a declaration] (and thereby) making the object as specially favoured and prosperous." When the subject is human and the object is God, brk means "to

\footnotetext{
${ }^{2}$ Geertz, "Comparing Prayer," 137-139.

${ }^{3}$ Prapod Assavavirulhakarn, "Blessing," in Encyclopedia of Religion, Second Edition, vol. 2, ed. Lindsay Jones (Detroit: Macmillan, 2005), 979-85. In this general view, all three meanings are seen to derive from one concept of "a benign power able to confer benefits upon humanity, individually or collectively" and thus this power also automatically invites humanity to offer praise.
} 
praise." ${ }^{4}$ Whether the meaning of the Hebrew root brk 'to praise' is a later derivation from 'to bless' or not is debated. ${ }^{5}$

The translation of brk into "to praise" instead of "to bless," is especially influential in theologically laden discussions that attempt to distinguish blessings directed towards God from blessings directed towards humans. But is this distinction justified: is praising God a unique activity, strictly different from other blessing acts? It will be demonstrated in this article that some of the ancient sources do not seem to appreciate such a division, at least not in a way similar to what the English assumes. Intriguingly, there are also contemporary theological voices that emphasize a close connection between praising and blessing: blessings bestowed upon creation meet their final destiny in the blessings offered to God. ${ }^{6}$ This view is in line with the suggestion that whatever the blessing activity performed in everyday life-whether praising God, asking for God's blessing, or performing blessing - it is an act that fosters a realization of the divine-human relationship and thus brings the divine sphere into the mundane. Another explanation of the connectedness between "praising" and "blessing" is that they are corresponding parts of a reciprocal act: a human being presents a gift (sacrifice, praise) to the divine and the divine accepts the gift by granting favor to the human being. The parties are deemed worthy of the exchange. ${ }^{7}$

\footnotetext{
${ }^{4}$ James K. Aitken, The Semantics of Blessing and Cursing in Ancient Hebrew, ANESSup 23 (Leuven: Peeters, 2007), 96-102, 11-17. Aitken further identifies two formulaic uses of the root: "profane" blessing where people declare each other blessed in the form of greeting (Ruth 2:4), and covenantal use, where the lists of blessed items and persons potentially became obscured from the original appeal to the divine being to ensure the covenantal agreement. Finally, there is the euphemistic use of the root to denote "to curse" (pp. 113-114). According to Aitken, the association of the root $b r k$ 'to bless/praise' with the root $b r k$ 'to kneel' is largely abandoned (pp. 6-7, 93-94). See also David J. A. Clines, ed., The Dictionary of Classical Hebrew, Vol II: bet-waw (Sheffield: Sheffield Academic Press, 1995), 267-271; Ludwig Koehler and Walter Baumgartner, eds., The Hebrew and Aramaic Lexicon of the Old Testament, Vol. I: 'alef-het. Translated and edited under the supervision of M.E.J. Richardson (Leiden: Brill, 1994), 159-160; Carl A. Keller (I-III) and Gerhard Wehmeier (IV-V), "Brk pi. to bless," in Theological Lexicon of the Old Testament, vol. 1: 'āb-ḥnp, ed. Ernst Jenni and Claus Westermann (Peabody: Hendrickson, 1997), 266-282.

${ }^{5}$ See Aitken, The Semantics of Blessing and Cursing, 94. In the Septuagint, the standard rendering of the Hebrew brk is

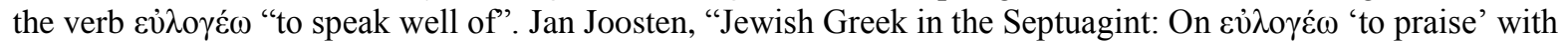
Dative," in Biblical Greek in Context: Essays in Honour of John A. L. Lee, ed. J. K. Aitken and T. V. Evans, Biblical

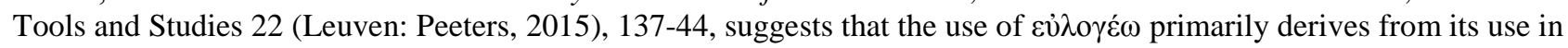
liturgy and worship and was then extended to translate other forms of blessing in scripture.

${ }^{6}$ This is suggested, for example, by Daniel G. van Slyke, "Toward a Theology of Blessings: Agents and Recipients of Benedictions," Antiphon 15 (2011): 47-60, in a largely Catholic framework. In later rabbinic prayers, petitions are often mixed with praises (e.g., Amidah), see Esther G. Chazon, "Looking Back: What the Dead Sea Scrolls Teach Us about Biblical Blessings," in The Hebrew Bible in Light of the Dead Sea Scrolls, ed. Nóra Dávid, et al., FRLANT 239 (Göttingen: Vandenhoeck \& Ruprecht, 2012), 155-171. Another aspect to consider is that when praising is blended with petitions of benediction, an avenue may be opened to understandings that include misfortune and suffering as part of the mystery of blessing.

7 Thus, Kent Harold Richards, "Bless/Blessing," in The Anchor Bible Dictionary, vol. I: A-C, ed. David Noel Freedman (New York: Doubleday, 1992), 753-755, thinks that the benefits of blessing are secondary and the relationship between parties is primary. Keller and Wehmeier, "Brk pi. to bless," 268, present as a starting point for the definition of the pi. of brk as "to gift someone with health-creating power or to declare someone so gifted."
} 
This does not mean that significant differences do not exist. A question that emerges from the uses of the root brk is whether God is always involved in blessings and in which ways. For example, the formulaic use of blessing in greetings or farewells may denote merely good aspirations and wishes rather than invoking the divine agent. ${ }^{8}$ But also when humans bless God, it can be asked if such praise-blessing is perceived as including two or three parties: does the speech act take place only between the human and the divine, oris a human/angelic audience necessary for the praise-blessing to be effective? ${ }^{9}$ In any case, both forms of blessing - that is, the act where humans wish each other well and the act where humans bless God-actually represent a eulogy type blessing (i.e., "blessed are you" or "I bless you"). This type of speech act is realized at the moment of its pronouncing: persons are spoken well of when they are blessed. Blessing in this sense is similar to vows or promises that have accomplished their complete action at the moment of their saying. ${ }^{10}$ At the same time, when humans such as priests bless other humans in the form of a benediction ("May the Lord bless you [. . .]"), the blessing is only partially fulfilled: something is expected to be realized in the future that is not yet evident or has not yet taken place, although uttering the plea for blessing is an important step in being blessed.

These sorts of differences have been sought and identified through speech-act theory, especially the various types of illocutionary acts that speech utterances are seen to do: humans do various things by speaking words, such as assert, promise, express, declare, commit, and direct. ${ }^{11}$ The utterance of the words involves performing the act. ${ }^{12}$ Words do what they say in so far as they are deemed to be well suited to the situation. For a speech-act to be effective, it must be uttered by the appropriate person

\footnotetext{
${ }^{8}$ Aitken, The Semantics of Blessing and Cursing, 113-114.

${ }^{9}$ If blessing is perceived as including three, rather than just two parties, a person pronouncing blessing - whether to another person through divine power or to the divine being through human acknowledgement - blessing is not merely an act of dialogue but rather conversation or performance.

${ }^{10}$ Assavavirulhakarn, "Blessing," 980.

${ }^{11}$ For the classic theory, see John L. Austin, How to Do Things with Words: The William James Lectures Delivered at Harvard University in 1955 (Oxford: Oxford University Press, 1976); John R. Searle, Speech Acts: An Essay in the Philosophy of Language (Cambridge: Cambridge University Press, 1969). For the Hebrew blessing, see Andreas Wagner, Sprechakte und Sprechaktanalyse im Alten Testament: Untersuchungen im biblischen Hebräisch an der Nahtstelle zwischen Handlungsebene und Grammatik, BZAW 253 (Berlin: de Gruyter, 1997), 253-286. For example, a praiseblessing such as "Blessed are You, O my God, who has opened to knowledge the mind of Your servant" in the final hymn of 1QS (11:15-16) as an illocution (words accomplishing things through their utterance) can be asserting or declaring that the speaker has received knowledge from God, and as perlocution (words effecting a response), may be affirming the speaker's authority as the knowing one among the audience. Praise-blessings can also be a promise to the audience concerning divine acts in the future: for example, in the midst of the battle, the people in the War Scroll are said to be praising: "Blessed is the God of Israel, who guards loving kindness for His covenant and the appointed times of salvation for the people He redeems. (1QM 14:4). Then again, in a text like the Barkhi Nafshi, the speaker first exhorts himself to bless ( "Bless, O my soul, the Lord..."), expressing commitment, followed by the actual blessing. Aitken, The Semantics of Blessing and Cursing, 113, is fairly brief about the types of speech-acts but seems to consider the Qal passive of brk not as declarative but as expressing volition: an indication that God will be praised. I think that the use of the Qal passive with relative clauses provides more nuances to study the speech-acts.

${ }^{12}$ According to Austin, How to do Things with Words, 159, blessings and curses are reactive performances: acts that present a reaction to someone's good or bad behavior.
} 
in an appropriate situation and with the appropriate intent by the person. ${ }^{13}$ The famous example of the "I do" wedding vow illustrates this point: the vow completes the act of marrying only in certain circumstances, by a certain person, and when certain conventions are accepted. Similarly, for utterances like "blessed are you" or "may he bless you," the social conventions of each cultural setting determine if/when the speech acts accomplish what they state (who can pronounce this, in what situations, and with what intentions). ${ }^{14}$

According to Aitken, the application of speech-act theory in the study of biblical blessings and curses has overshadowed earlier tendencies to identify magical ideas in the act of blessing and cursing. ${ }^{15}$ While speech-act theory teaches us that words have power, this power is not thought of as magical or intrinsic to the words, but is explained as effective speech acts. As a result, blessings have been increasingly understood as prayers and petitions, rather than spells or invocations. Earlier scholarship typically created models of evolution whereby early or "primitive" forms of religion were imbued with a much greater sense of magic. In one model, for example, the Hebrew Bible was thought to reflect three stages of evolution: first, a magical stage, where blessings and curses are self-fulfilling and contagious; second, a cultic stage, where certain ceremonies are required to evoke God to action; and in the final stage, blessings or curses come directly from God, and they are dependent on the ethical values proclaimed by the prophets. ${ }^{16}$ Earlier scholarship is noteworthy for its resistance to applying the concept of "magic" to anything that was deemed to be a "genuine" act of blessing. ${ }^{17}$

This rejection of magic is, however, based on an outdated dichotomy between magic and religion, where one was seen as more developed (religion) than the other (magic), one as representing "our"

\footnotetext{
${ }^{13}$ Aitken, The Semantics of Blessing and Cursing, 14.

${ }^{14}$ Aitken, The Semantics of Blessing and Cursing, 18-19, notes some semantic conventions that help determine the force of an utterance, such as the attention-grabbing particles hinne, 'atta (now!), and the markers of immediacy of command -na, long imperative.

15 Aitken, The Semantics of Blessing and Cursing, 13. This is also noted by Jeff S. Anderson, "Curses and Blessings: Social Control and Self Definition in the Dead Sea Scrolls," in The Dead Sea Scrolls in Context: Integrating the Dead Sea Scrolls in the Study of Ancient Texts, Languages, and Cultures, vol. I, ed. Armin Lange et al., VTSup 140 (Leiden: Brill, 2011), 47, who sees the magical properties and performative power as two alternatives: “(. . .) blessing and curses were potent, but not because of the magical power of words or the soul, but as performatives uttered in proper ritual contexts" (p. 59). I will question whether these two are exclusive alternatives, or rather work at different levels of analysis (one more profoundly cognitive, the other socio-linguistic; both of them having to do with ritual context). Jesper Sørensen, A Cognitive Theory of Magic (Lanham: Altamira, 2007), 22-23, objects to any theories that distinguish between causal thinking and performative thinking as two opposite modes. Thus to ask whether ritual blessing is perceived as truly effecting a change or merely expressing or persuading a change may not be helpful.

${ }^{16}$ Aitken, The Semantics of Blessing and Cursing, 9, referring to J. Hempel's theory from the 1960s.

${ }^{17}$ E.g., Josef Scharbert, "BRK," in Theological Dictonary of the Old Testament, vol II: bdl-gālāh, ed. G. Johannes Botterweck and Helmer Ringgren (Grand Rapids: Eerdmans, 1975), 286, 293, 303. See also Aitken, The Semantics of Blessing and Cursing, 11, on Gerhard von Rad and the view that the idea of blessing poured out like fluid is pre-Israelite. Often patriarchal blessings that transferred the power and inheritance to the next generation were referred to as having an old magical basis.
} 
religion, and the other "their" magic. ${ }^{18}$ Therefore, it is time to revisit magic from a cognitive perspective and see what implications this has on studying blessing. ${ }^{19}$

\section{Blessing is Action: Cognitive Perspectives}

Cognition is not only about processing information but also entails predictions. Jesper Sørensen's cognitive theory of magic starts with a discussion of the existence of distinct ontological domains in the human mind (physical, biological, psychological) — that are innate or develop normally in early childhood-from which we make assumptions and/or generate expectations of our environment. Physical objects do not have any innate kinetic energy in them, and their movements are usually explained by mechanical causality (billiard ball moving another ball). In the biological domain, actions are explained by teleological or instrumental causality: an agent with a goal exerts force on an object. People, of course, may mistakenly identify any moving thing as an animate agent. It is important, however, to distinguish between a thing that is moved and an animate thing that moves itself. Further, humans more often ascribe an essence to things in the biological domain than in the physical domain: changes in the outward properties of creatures do not necessarily mean similar change in their essence. In the psychological domain, humans have representations of other minds (theory of mind), and a tendency to ascribe causal-intentionality to explain actions (belief-desire reasoning). ${ }^{20}$

Magical thinking is based on the blending and mixing of basic ontological categories in ways not expected in everyday life. In common experience, the essence of a thing does not change from one category to another, nor is the relation between things changed except through physical laws of

\footnotetext{
${ }^{18}$ For a critique of the use of magic as a pejorative term, see, for example, Ilkka Pyysiäinen, Magic, Miracles, and Religion: A Scientist's Perspective (Walnut Creek: AltaMira Press, 2004) and István Czachesz, "Explaining Magic: Earliest Christianity as a Test Case," in Past Minds: Studies in Cognitive Historiography, ed. Luther H. Martin and Jesper Sørensen, Religion, Cognition and Culture (London: Equinox, 2011), 141-165, esp. 142-143. However, Pyysiäinen does not suggest getting rid of the distinction between "magic" and "religion" but re-using it. In magical thinking, counterintuitive agents are thought to act upon the world, whereas in religious thinking, humans are thought to act upon the supernatural world. Magic needs religion, a symbolic meaning system to explain ineffective ritual or to prescribe rituals that will be performed despite the impossibility of verifying them. "Magic has the potential to provide individual motivation, while religion provides a context of meaning and helps to avert failures in the practice of magic" (p. 111).

${ }^{19}$ Florentino García Martínez, "Magic in the Dead Sea Scrolls," in Qumranica Minora II: Thematic Studies on the Dead Sea Scrolls, ed. Eibert J. C. Tigchelaar, STDJ 64 (Leiden: Brill, 2007), 107-130, notes that the magic represented in the Qumran texts "is not magic of the marketplace and cannot be dismissed as an accidental expression of popular religion" (p. 110). The magic in the scrolls is learned magic, and expresses the elaborate worldview of the authors. García Martínez categorizes magic in the scrolls in two groups: texts that refer to magical practices or divination and texts that can be considered to function themselves in magical practices, such as incantations, exorcism, and apotropaic prayers. Here, a cognitive perspective on magic potentially brings forward a much broader understanding of magic than the one employed by García Martínez.

${ }^{20}$ Sørensen, A Cognitive Theory of Magic, 32-38. At the same time, the human mind has domain-general properties that enable flexibility and similar representational formats across distinct domains, see pp. 38-43.
} 
causality. In magical thinking both are possible. Human categorization involves both iconicity (identity on the basis of outward perceptual similarity) and indexicality (identity on the basis of assumed intrinsic properties revealed by outward signs), and these mechanisms play a role in the ways the human mind connects the "sacred" domain (with non-intuitive properties) with the "profane" domain (with intuitive properties). ${ }^{21}$ The sacred domain is associated with the profane domain by employing ideas of their outward similarity (iconicity) or of their "inner" similarity (indexicality; e.g., transferring sacred power by contagion). "Similarity and contagion enable representations of 'causal' connection between two otherwise distinct domains of reality." 22 Sørensen distinguishes two ideal types of magic: 1) manipulative magical action, in which the state of affairs inside one domain is changed by manipulating elements in another domain; the relation between elements is changed (e.g., a voodoo doll has a special relation to the person harmed, exorcism, evil eye), and2) transformative magical action, in which essential qualities from one domain are transferred to another domain (e.g., ingestion of the body of Christ during the Eucharist; an amulet transfers properties to its carrier). ${ }^{23}$ Magical actions thus involve such theories of why and how the

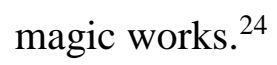

István Czachesz objects to Sørensen's ideal types and argues that such analogical reasoning of how distinct domains are linked in magical action often occurs only retrospectively and not as an underlying mechanism of magical action. He defines magic in etic terms as something that can (normally) be falsified through modern scientific methods: it is "illusory manipulation of visible or invisible realities" which can be shown to be based on false causal connections. The magical effects to be studied have implications in the natural world, not (only) in the heavenly or spiritual reality (such as salvation, removal of sins, spiritual healing). ${ }^{25}$ Furthermore, in his view, magic does not necessarily involve supernatural agents: for example, healing can be ascribed to human or natural agency but yet be proven illusory. Nevertheless, supernatural agents were seen to be all-present in the ancient world, so the worldview itself could be labelled as "magical" but such an etic label does not help in the analytical work on magic, that is, in the attempt to identify certain kinds of causeeffect relationships. ${ }^{26}$

\footnotetext{
${ }^{21}$ Sørensen, A Cognitive Theory of Magic, 43-44, 63-64.

${ }^{22}$ Sørensen, A Cognitive Theory of Magic, 4-5.

${ }^{23}$ Sørensen, A Cognitive Theory of Magic, 95-139.

${ }^{24}$ István Czachesz, "A Cognitive Perspective on Magic in the New Testament," in Mind, Morality, and Magic: Cognitive Science Approaches in Biblical Studies, ed. István Czachesz and Risto Uro (Durham: Acumen, 2013), 166.

${ }^{25}$ Czachesz, "Explaining Magic,” 141-165, 147; idem, “A Cognitive Perspective on Magic,” 164-179.

${ }^{26}$ Czachesz, "Explaining Magic," 146. Thus, for example, baptism could be seen both as non-magic (the effect is forgiveness which is not verifiable or falsifiable) or magic (the effect is, e.g., protection from disease).
} 
In the following analysis, therefore, the investigation includes asking to what extent the act of blessing in general may have included the blending of domains, if something sacred is transferred or a domain is manipulated to change another, and what the effects are, and where in particular this blending takes place in ritual actions that are ascribed supernatural agency. In general, Czachesz's understanding of the necessary cognitive ingredients in magical thinking aligns with Sørensen's: magic relies on superstitious conditioning and on innate intuitions about agency and contagion. ${ }^{27}$ The role of superstitious conditioning can be especially helpful: as demonstrated in many experiments, people easily create beliefs that their behavior has a correlation with some stimulus, even though the stimulus may occur quite randomly or at regular intervals. ${ }^{28}$

It is to be noted that ritual settings are learning environments for such conditioning since links may be actively implied or even taught there: raising hands makes the blessing more effective, or receiving the blessing at a correct time is believed to be better than at another time. ${ }^{29}$ Ritual actions are characterized by following mysterious, not everyday rules; as being rigid; as taking place at a specific time, place, and in a prescribed manner; and as being non-intentional in the sense that the sub-actions cannot be changed or modified in order to reach the desired goal. ${ }^{30}$ Rituals differ from ordinary actions in that they are removed from the ordinary instrumental domain (goal-demotion): regarding a blessing, a person is not made prosperous in the normal manner by giving him gifts, training his skills, or curing him, but by some other invisible and mysterious means. Cognitively, thus, belief in the efficacy of the ritual action depends on many human cognitive capacities, such as tendency to the overestimation of causality ("better safe than sorry") and the search for agency.

We may initially ask when a blessing might occur as an action where sacred properties are blended with the mundane. The practice of wearing amulets, like the famous Ketef Hinnom priestly blessing on silver plates, or tefillin, implies the idea that the inscribed words mediate the transference of sacred, protective power to its carrier; such instruments enable human intuitions of contagion, that is, belief that positive (or negative) qualities can be transferred through contact. ${ }^{31}$ Also, the laying on of hands in blessing (Gen 48:17; Lev 9:22) is an intuitive bodily gesture in terms of mediation.

\footnotetext{
${ }^{27}$ Czachesz, "Explaining Magic," 151-55; idem, “A Cognitive Perspective on Magic," 171-174, also takes note of the role of miracle stories in early Christianity: miracle stories spread successfully because of their counterintuitive properties, and their success again provides schemas for interpreting new events.

${ }^{28}$ Czachesz, "A Cognitive Perspective on Magic," 166-167.

${ }^{29}$ Not all blessings are necessarily embedded in ritual settings; yet the purpose is here to investigate what happens when they are.

${ }^{30}$ This understanding relies heavily on Roy A. Rappaport, Ritual and Religion in the Making of Humanity, Cambridge Studies in Social and Cultural Anthropology 110 (Cambridge: Cambridge University Press, 1999).

${ }^{31}$ See Gabriel Barkay et al., "The Amulets from Ketef Hinnom: A New Edition and Evaluation," BASOR 334 (2004): 41-71. Tefillin do not contain direct blessings, but Yehudah B. Cohn, Tangled up in Text: Tefillin and the Ancient World,
} 
However, when God is blessed, the transformative logic does not seem to work, at least not theologically. In biblically oriented traditions, humans cannot transfer any sacred power to God. Yet blessing God can be understood as creating a "channel" to the sacred domain that enables a change in the cosmic world and its order. In apotropaic hymns, the praising of God is even explicitly said to frighten evil spirits: And I, the Instructor, proclaim His glorious splendor so as to frighten and to te[rrify] all the spirits of the destroying angels, spirits of the bastards, demons (. .) (4Q510 14-5). ${ }^{32}$ Moreover, when a congregation is imitating heavenly worship, as in Songs of the Sabbath Sacrifice (4Q400-407), the similarity of the earthly domain to the sacred domain triggers in the minds of the worshippers the idea of a manipulative relationship between the domains: by imitating the angelic life, humans may change the relations between the otherwise distinct domains.

Rituals as actions are "performed in order to change some part of the world, and as such they involve exertion of force. ${ }^{33}$ Ritual actions are actions in the sense that they include representations of agency (someone/something doing something), often of instruments (by which something is done) and patients (on or to whom something is done), and purposeful movements. Agency involves the representation of force, and some aspects of rituals are special - they belong to the sacred domain, special agency. Utilizing Thomas Lawson's and Robert McCauley's ritual theory, Sørensen distinguishes between agent-based, action-based, and object-based (instrument-based) magical agency in rituals according to where the emphasis of divine presence and sacred sphere is placed. ${ }^{34} \mathrm{I}$ will use this framework to analyze agency in variations of blessing in the Dead Sea Scrolls.

\section{The Dead Sea Scrolls as a Case Study: Magical Action, and Special Agency}

The well-known priestly blessing in Numbers 6:22-27 is brief and somewhat loose from its context: it comes after the Nazirite law (Num 6:1-21) and before the consecration of the tabernacle and its altar (Num 7-8). In that textual setting, it underlines the priestly hierarchy over the Israelites, as

\footnotetext{
Brown Judaic studies 351 (Providence: Brown Judaic Studies, 2008), argues that they functioned as long-life amulets on the basis of the promise in Deut 11:21.

${ }^{32}$ The verb brk is not used in this sentence but is found [reconstructed] in 4Q510 11 in titular usage: "[...] praises. Ble[ssings to the K]ing of Glory. Words of thanksgiving in psalms of [...] to the God of knowledge" as well as in 4Q511 (e.g., $13-5$ ). Translations follow, with possible minor modifications, Emanuel Tov, ed., The Dead Sea Scrolls Electronic Library: Texts and Images (Partially based on The Dead Sea Scrolls Reader, edited by Donald W. Parry and Emanuel Tov, morphological analysis by Martin Abegg, Jr., produced by Noel B. Reynolds, associate producer Kristian Heal [Leiden: Brill], 2006).

33 Jesper Sørensen, "Charisma, Tradition, and Ritual: A Cognitive Approach to Magical Agency," in Mind and Religion: Psychological and Cognitive Foundations of Religiosity, ed. Harvey Whitehouse and Robert N. McCauley (Walnut Creek: AltaMira Press, 2005), 173. This definition may also embrace rituals that are meant to preserve order, to prevent the world from changing: rituals can exert force that cancels the otherwise expected change.

${ }^{34}$ Sørensen, A Cognitive Theory of Magic, 64-74.
} 
priests have an important role both in Nazirite rituals and in the tabernacle. ${ }^{35}$ But it tells little about the underlying cognitive mechanism on which such ritual action would have relied.

In comparison, the priestly blessing in the covenant ceremony in the Qumran Community Rule (1QS 1-3) is more elaborate as will be seen below. In the covenant entry setting, it is marking boundaries of who is in and who is out: the lot of God is blessed and the lot of Belial is cursed. As suggested by Jeff Anderson, blessings and curses also have other social functions: they function as means of expressing power in a situation where the persons most likely lacked power and as a means of social control in a social movement where commitment was important. ${ }^{36}$ But what happened to a person who was blessed? Were the blessings perceived as having magical force in the covenant ritual or elsewhere $?^{37}$ Where might the special agency lie in the case of blessings?

\subsection{Agent-based Agency}

Priests, divinely distinguished personnel, who bless a person once a year can be intuitively ascribed more efficacy than when a person who blesses him/herself daily, provided that one grows up seeing the priestly class as having special privileges in society and comes to believe that they are selected by God for their task. This seems to be a prerequisite in the covenant renewal text of 1QS 1-3.

While the initiates are being inducted into the Covenant, the priests and the Levites shall continuously bless the God of deliverance and all His veritable deeds. All the initiates into the Covenant shall continuously respond “Amen, amen.” (1QS 1:18-20)

Then the priests are to bless all those foreordained to God, who walk faultless in all of His ways, saying "May He bless you with every good thing and preserve you from every evil. May He enlighten your mind with wisdom for living, be gracious to you with the knowledge of eternal things, and lift up His gracious countenance upon you for everlasting peace.” (1QS 2:1-4)

\footnotetext{
35 The priestly privilege is probably late in biblical texts. In Deut 27:12-13, the task of blessing belongs to all the tribes, Keller and Wehmeier, "Brk pi. to bless," 270-280.

36 Anderson, "Curses and Blessings," 52-54. The covenant ritual combines the priestly blessing (Num 6) with the covenant blessings and curses (Deut 28), as already in Joshua (8:33-34).

37 That the entry into the covenant was perceived to have efficacious elements is clearest in the Damascus Document. According to CD 16:4-5, on the day the member entering the covenant gives the oath, the angel Mastema will leave him; covenant commitment was tied to the cosmic sphere. In the case of the covenant ritual in $1 \mathrm{QS}$, there are many other actions involved: recounting God's deeds, praising God, confession of sins, blessing and cursing, entering in hierarchical order, and purification by water. Magical agency could be believed to lie in any of these, or in a combination of these.
} 
The sacred priestly lineage created a link to the sacred domain. ${ }^{38}$ The priests in 1 QS are higher in hierarchy than the Levites who pronounce the curses (cf. 1QS 2:19-22). Even though in reality their lineage is a construction, such as the sons of Zadok title elsewhere may suggest, ${ }^{39}$ the title of priest is an index pointing towards the mythic past. It is also noteworthy that the blessing is pronounced collectively by the priests. One could argue that if people were categorized according to their (assumed) tribal past, "priestly" entrants into the covenant may have claimed a right to join in pronouncing these blessing. It is more likely, however, that the priests represent a leadership class here. In any case, it is not one individual, a high priest, but a class of priests that is relied on.

In comparison, a different agency is present in the Rule of the Blessing $1 \mathrm{QSb}$, where several blessings are inscribed to the maskil, the wisdom teacher or wise one. ${ }^{40} \mathrm{He}$ is to bless several groups of people: those who fear God; the sons of Zadok, the priests; and the prince of the congregation. The one pronouncing the blessings is not, at least explicitly, a priest. Instead, the priests are themselves being blessed.

Words of blessi[ng] belonging to the maskil, by which to bless those who fear [God, those who do] His will and keep His commandments, (. . .) "May the L[ord] bless you [from His holy habitation ...]" (1QSb 1:1,3)

Words of blessing belonging to the mas[kil, by which to bless] the Sons of Zadok, the priests, chosen by God to uphold His covenant for[ever, ...] "May the Lord bless you from His [ho]ly [habitation]! May he set you, perfected in honor, in the midst of the Holy Ones; [may He re]new for you the [eternal] covenant of the priesthood. May He make a place for you in the holy [habitation.] May He ju[dge a]ll princes by the measure of your works, all [leaders] of the nations by what you say. May

\footnotetext{
38 There is a considerable amount of attention on the priestly interest in the scrolls. For the "priestly magnetism" during this period, see Joseph L. Angel, "The Traditional Roots of Priestly Messianism at Qumran," in The Dead Sea Scrolls at 60: Scholarly Contributions of New York University Faculty and Alumni, ed. Lawrence H. Schiffman and Shani Tzoref, STDJ 89 (Leiden: Brill, 2010), 27-54. That the priestly lineage, however, was not the reason for the emergence of the movement is argued now, e.g., by John J. Collins, Beyond the Qumran Community: The Sectarian Movement of the Dead Sea Scrolls (Grand Rapids: Eerdmans, 2009), 46-48. According to the Temple Scroll (11Q19 60:9-11), it was a priestly duty to bless.

${ }^{39}$ Charlotte Hempel, "The Sons of Aaron in the Dead Sea Scrolls," in Flores Florentino: Dead Sea Scrolls and Other Early Jewish Studies in Honour of Florentino Garcia Martinez, ed. Anthony Hilhorst et al., JSJSup 122 (Leiden Brill, 2007), 207-224, provides a study of priestly terminology in S: "Aaronite/sons of Aaron" was both a generic, traditional name for the priestly class and a community-specific term for priestly leaders, along with the (probably later) "Zadokite/sons of Zadok."

${ }^{40}$ See Robert Hawley, "On Maskil in the Judean Desert Texts," Hen 28 (2006): 43-77, for a suggestion that the title is used in the sense of a section marker "for instruction," rather than an office title (thus, the beginning could be translated as "words of blessing, for instruction, to bless [. . .]"). Nevertheless, someone is expected to pronounce these blessings upon groups of people.
} 
He make the firstfruits of [every pleas]ing thing your inheritance; may He bless all mortal counsel by your hand!" (1QSb 3:22-23, 28)

Yet there is a clear priestly hegemony in that the priests come before the prince. The priests are blessed but they are also said to be mediators of blessing to others.

Different actors are also present in the War Scroll. In 1QM 13, the ones pronouncing blessings (to God and those who serve him) are "(. . .) his brothers the [pr]iests, the Levites, and all the elders of the serekh with him" (1QM 13:1). The wartime blessings and curses and other ritual activities are orderly, led by high cultic and military personnel together. These variations show that there are other alternatives to priests as agents of blessing.

Could the agency also be in those who receive the blessing ${ }^{41}$ The recipients in $1 Q S$ are characterized as the "lot of God" - they are already chosen by divine will and knowledge and thus the blessing is efficacious because the recipients have a correct relationship to God. However, cursed is also the person who enters the covenant "with idols in his heart" and blesses himself (hitp. brk), saying "Peace be with me, though I walk in the stubbornness of my heart" (1QS 2:11-12, cf. Deut 29:18-19). Even though being a recipient of the priestly blessing, his inner being has not changed; the power of the blessing turns to a curse for those whose heart does not enter the covenant with their body and whose inner behavior does not correspond to their outer behavior. ${ }^{42}$

\subsection{Action-based Agency}

If magical agency occurs during the act, it would not matter who performs the action on whom; the action must only be correctly performed. Aitken notes that the archaic language that is used in many rituals evokes beliefs in the effectiveness of the ritual. Similarly, Sørensen explains that ritual effectiveness is often seen to lie in nonsense words or rigid forms of liturgies. ${ }^{43}$ However, the Aaronic

\footnotetext{
${ }^{41}$ Although Sørensen, A Cognitive Theory of Magic, 75, identifies agent, action and object as the most important agencies where blending takes place, he also notes that time, location, and participants can be connected to sacred space.

${ }^{42}$ In the two-spirit discourse section of 1 QS (3:13-4:26), the lots are described differently: each person has a part both in the spirit of truth and spirit of falsehood, which are like essences in a person and produce their fruit accordingly. If these spirits are predetermined, the question of what difference any petition or blessing can make arises. The texts do not state this directly. From a ritual perspective, it is conceivable that specific ritual practices arose just in order to mitigate this anxiety or affirm that participants who follow the ritual fully and correctly are among the right lot. The problem reminds one of the challenge in apotropaic intercession: it requires persuading the audience that divine beings are still supposed to be in charge but yet danger can be averted, see Marian W. Broida, Forestalling Doom: "Apotropaic Intercession" in the Hebrew Bible and the Ancient Near East, AOAT 417 (Münster: Ugarit Verlag, 2014). Daniel C. Timmer, "Sectarianism and Soteriology: The Priestly Blessing (Numbers 6,24-26) in the Qumranite Community Rule (1QS)," Bib 89 (2008): 389-396, argues that in 1QS the election for God's lot replaces the covenant fidelity as means of obtaining blessings. However, he ignores the ambiguity in the matter: those entering the covenant among God's lot might also be cursed if they do not show covenant fidelity.

${ }^{43}$ Sørensen, A Cognitive Theory of Magic, 4.
} 
blessing, while referring to a well-known archaic model, is not rigid and without variation in the scrolls.

The contents of the Aaronic blessing are noteworthy in 1QS 2:1-4. They are pronouncedly immaterial: wisdom, knowledge of eternal things, everlasting peace:

Numbers 6:24-2644

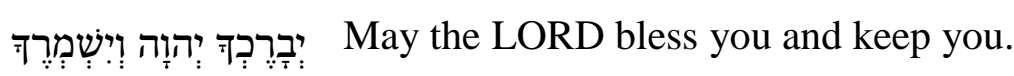

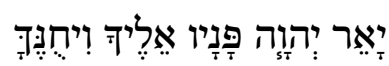

May the LORD make his face to shine upon

you, and be gracious to you.

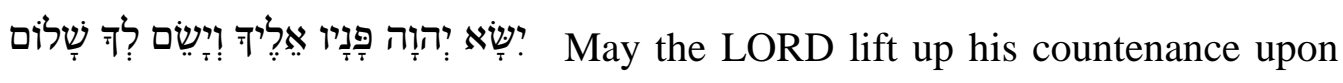
you, and give you peace.

1QS $2: 2-4^{45}$

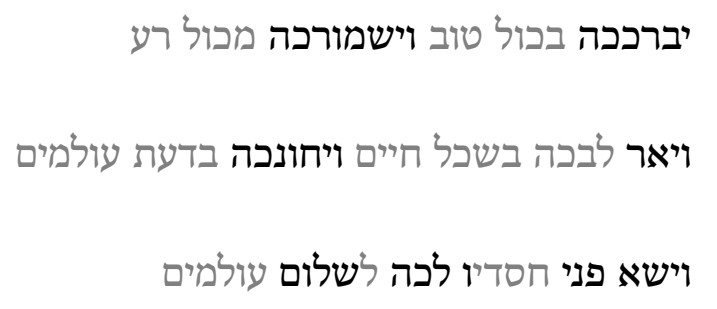

May He bless you with every good thing and keep you from every evil.

May He enlighten your mind with wisdom for living, and be gracious to you with the knowledge of eternal things.

May he lift up His gracious countenance upon you for everlasting peace.

These additions to the priestly blessings are significant: the traditional words carry a special character in terms of the Aaronic blessing but, at the same time, these blessings could be seen to be fulfilled in the movement where one was to study and learn. What supports the belief in the efficacy of this blessing is confirmation bias: the tendency to seek evidence that is consistent with the hypothesis and to ignore other information. ${ }^{46}$ So even if the blessed one were to face misfortunes, one would seek

\footnotetext{
${ }^{44}$ See Timmer, "Sectarianism and Soteriology," 390, for the three bipartite blessings.

${ }^{45}$ For the scriptural phraseology in the additions to the priestly blessing, see George J. Brooke, "Reading, Searching and Blessing: A Functional Approach to Scriptural Interpretation in the Yahad," in The Temple in Text and Tradition: A Festschrift in Honour of Robert Hayward, ed. R. Timothy McLay (London: Bloomsbury T\&T Clark, 2015), 140-156, esp. 151-152.

${ }^{46}$ Czachesz, "A Cognitive Perspective on Magic," 170-171.
} 
confirmation in what the blessing as a knowing one with an enlightened heart meant, rather than what would speak against it. ${ }^{47}$

In contrast, very different contents of the blessing are found in 11QSefer ha-Milhamah. "Blessed be you (referring to Israel) in the name of God Most High" (11Q14 1ii:3-4) seems to rely on the rare epithet of God, God's special name. ${ }^{48}$ But now the blessings are mostly earthly, referring to agricultural prosperity, good health, and safety from wild beasts, as in this passage: "God Most High will bless you and shine his face upon you... to give you frui[t], produce, grain, wine and oil in abundance; and the land will produce for you [d]elightful fruit so that you will eat and grow fat. vac And none will miscarry in your land, and none be sick, no blight and mildew will be seen in its grain..."(11Q14 1 ii 7-12). Such misfortunes would be much harder to explain away.

In comparison, the blessings in $1 \mathrm{QSb}$ are very elaborate. Some Aaronic overtones are heard but not very explicitly. Locations, places, and movement seem now more pronounced: God blesses from his holy habitation, he opens the heavens, he sets the blessed ones in the midst of holy ones, and he lifts up the blessed prince. There are some sections with repetition that suggest special force for the words. For example the word יחונכה "may he grace you” is repeated in almost every line in 1QSb 2:22-28.

This redundancy removes the symbolic, referential interpretations of the word, and instead strengthens its efficacious character. ${ }^{49}$

Furthermore, peculiar blessing is found in Damascus Document $\left(4 \mathrm{QD}^{\mathrm{a}}\right)$, whereby a rebellious member of the Qumran movement is expelled by pronouncing a praise-blessing to God:

\footnotetext{
${ }^{47}$ Furthermore, metaphors have been suggested to be important in making ritual language effective in tying together two distinct domains; see Sørensen, A Cognitive Theory of Magic, 21-22. The blessing itself is filled with metaphors: Herbert Chanan Brichto, "Priestly Blessing," in Encyclopaedia Judaica, vol. 16, 2nd ed., ed. Michael Berenbaum and Fred Skolnik (Detroit: Macmillan Reference, 2007), 510-511, suggests that the primary model in "shining" of the face is that of a court when the king grants an audience to the subject and thus will see the face of the king. The "lifting up the face" may have to do with facial expressions: it is the opposite of putting the face down, i.e., frowning. For the light as a metaphor of the law in the Qumranic blessing, see Brooke, "Reading, Searching and Blessing," 152.

${ }^{48}$ This form of the name, El Elyon, is found in the Hebrew Bible only in the blessing of Abraham by Melchizedek in Gen 14, but is frequent in Jubilees and in Genesis Apocryphon, and also found in $1 \mathrm{QH}^{\mathrm{a}}$ (e.g., 12:31). The name too is a means/instrument of blessing here; see below on object-based agency.

${ }^{49}$ Sørensen, A Cognitive Theory of Magic, 23,87-90. Many other examples are found, most prominent among the Dead Sea Scrolls perhaps being the Songs of the Sabbath Sacrifice. The lengths of the songs are without any proportion to the information transmitted, and the repetitive, highly formulaic and redundant language encourages focusing on the saying, rather than on what is said. Each song is dated to a specific Sabbath (13 songs). It is thus the time, the place, and the words that here possess special character. Cf. also the sixfold repetition in Deut 28:3-6 that according to Keller and Wehmeier, "Brk pi. to bless," 269, "clearly indicates the character of the effectual, energizing word." Cf. the statement by Broida, Forestalling Doom, 25, that "words operate more or less as things." Blessings are something that attach themselves or move into a person. In thinking about an abstract concept such as blessing, the human mind may easily create representations of an essence that flows into one's body, or of peaceful, protective space around oneself.
} 
Being in rebellion let him be expelled from the presence of the Many. The priest appointed [ov]er the Many shall declare, saying: Blessed are you, Almighty (God) (ברוֹ את אונ הו הכול), ${ }^{50}$ in your hand is everything, and who makes everything. You established [pe]oples in accordance with their families and tongues for their nations, but made them go astray in a trackless void. But our ancestors you did choose and to their descendants you gave your truthful statutes and your holy laws, which if a man does them, he shall live. You have set boundaries for us and cursed those who transgress them, for we are the people of your redemption and the sheep of your pasture. You cursed their transgressors but preserved us. (Thereupon) the one being expelled shall depart. (4Q266 11:7-14)

By praising God who has set this order, established clear boundaries and cursed transgressors, the speaker is transferring all responsibility to God, and moving the member from an insider-membership status to that of an outsider. ${ }^{51}$ In the actual ritual, participants may also have cursed the apostates (4Q266 11:17-18), but in this textual representation, the expulsion takes place by praising. This may be symptomatic of the role praise-blessings take in this period, and the uses of blessings for warding off evil.

\subsection{Object-based Agency}

The Scrolls give us hardly any explicit evidence of items or instruments used in rituals that would have been thought to carry special properties. As seen above, in some settings, words could have been perceived as things that mediate the force needed for the desired result. This was reinforced by the belief that God created these words and opened a fountain for praise, as found in the 1QHodayot and 4QInstruction:

\footnotetext{
${ }^{50}$ However, there are problems in readings here. The second scribal hand is probably responsible not only for the interlinear additions but also for the word "strength" (note the medial nun instead of final nun). This would be a peculiar substitute for God's name (but see Joseph M. Baumgarten, "A New Qumran Substitute for the Divine Name and Mishnah Sukkah 4.5," The Jewish Quarterly Review 83, no. 1/2 (1992): 1-5.). Also, in the new digital image (Leon Levi Digital Dead Sea Scrolls, Plate 706, frg 1, B-370995, http://www.deadseascrolls.org.il), the interlinear reading does not look like ברוذ את, as read by Joseph M. Baumgarten, Qumran Cave 4.XIII: The Damascus Document (4Q266-4Q273), DJD 18 (Oxford: Clarendon Press, 1996), 76-77, but the first word is rather בُרוב or and the second seems to have had a lamed that was erased. Isaiah 40:26 might suggest an original reading as something like אובים (God is) great in strength." Even if the blessing formula is not in the text, the passage still contains praise and direct address of God.

${ }^{51}$ In terms of a speech-act, this is an indirect act, since it does something other than the speech itself implies.
} 
vacat You created breath for the tongue, and You know its words. You determined the fruit of the lips before they came about (...), so that all who know You might bless You according to their insight forever [and ever.] vacat $\left(1 \mathrm{QH}{ }^{\mathrm{a}}\right.$ 9:27-31)

(...) [for the utterance of] your lips He has opened up a spring so that you may bless the Holy Ones, and (so that) as (with) an everlasting fountain you may praise His n[ame. (4Q418 81+81a 1)

Yet, there is one potentially significant medium present in the 1QS ritual setting: water. What is at play here is the belief system that demanded purification from impurities but, at the same time, presented a claim that not all purification was effective (1QS 3:4-6). Furthermore, there is evidence of blessings in purification rituals. In 4QRitual of Purification A, a person may even utter the blessings while in the water and praise God who has himself uttered words that distinguish the pure person from an impure person. ${ }^{52}$

And afterwards he will enter the water[ and wash his body and bless.] He will recite and say: Blessed are y[ou, God of Israel, ] by what comes of Your lips [the purification of all (people) has been required. To be separated(?) from all] impure people according to their g[uilt, they could not be purified in water of purification ] (4Q414 2ii +3,4 5-8)

From the viewpoint of an outside observer, the event of pronouncing praise-blessings in connection with the water and appealing to prior divine utterings for the effectiveness of the purification could encourage an interpretation where the blessings were affecting the water to make it produce the desired purification. We can only speculate whether or not this was believed to take place during the ritual. Concepts that are based on intuitive magical thinking may also "feel right," are cognitively easy to transmit forward and are intuitively satisfying - "blessed water" could be one such concept. 4QRitual of Purification A only gives hints towards this direction but is nevertheless a significant testimony of connecting praise-blessings with water purification.

Another aspect to pay attention to is the blending that occurs in connecting the concept of purity with the concept of blessing. Human conceptualization is constrained by its ability to form mental images

\footnotetext{
52 The text is fragmentary, and it is also possible that the blessings were pronounced after the immersion. In 4Q512 29$324-5$, the association between the water and the blessing is made on the basis of the words "[in] water" in line 4 and "he blesses there" in line 5. Cf. also 4Q512 33+35 5-6. The connection with water is also clear in the metaphor of a spring within a person that pronounces blessings; see above 4Q418 81+81a 1.
} 
only at a medium level: one can form a mental image of "cup" (on the basis of experience of individual and different cups) but one cannot form a mental image of "tableware" without a collection of individual pieces of cups and plates. ${ }^{53}$ In the same way, to imagine the concept of "blessing" one must imagine it as being constituted of some sort of life-giving essence or its effects as being constituted of several things (such as health, long life, protective essence). "Praise-blessing", for its part, is constituted of verbal acts of acknowledgement. Blending together the concept of purity with the concept of blessing adds another mental image with which to understand the phenomenon of blessing: that of being pure and clean. The passage above does not directly connect the purified person to being blessed, but the inference is not far, as the person who blesses God is purified whereas the outsider who does not bless is not.

\section{Implications and Conclusions}

Blessing as communication and blessing as (ritual) action are rich areas of study that cannot be fully explored in the scope of one article. What I aimed to do here was to pay attention to the various levels of analysis and outline what a cognitive perspective on blessing has to offer. Even in the study of textual sources, scholars may focus on different questions, such as varying blessing formulations (words), the performative tasks the blessings fulfill (speech acts), or the ways in which blessings are spoken of (tradition), noting, however, that these are written representations and snapshots of a much wider oral world. Semantically, the Hebrew root brk is used in many ways, and a single translation "to bless" does not work in all situations, but neither does a strict division between "blessing" and "praising." Studying blessings not merely as communication but also as behavior is much more difficult from literary sources, but at least some of the belief structures and conceptual alternatives can be inferred from the texts that envision a ritual setting. The aim of introducing some new cognitive perspectives was to ask fresh questions of the available data and to facilitate comparative work. The cognitive model presented in this article offers at least some correctives to the scholarly embarrassment and the tendency to marginalize magical efficacy in connection with blessing.

Whereas the earlier scholarship associated magical beliefs in blessings to primitive religion, later scholars have turned to speech-act theory to show that words do carry power when applied according to agreed conventions. But this level of analysis alone is not sufficient, since, especially in a ritual setting, the human mind is directed toward searching for magical agency and seeing ordinary actions as producing unordinary effects. Rituals are learning environments for superstitious conditioning

\footnotetext{
${ }^{53}$ Sørensen, A Cognitive Theory of Magic, 39-40.
} 
whereby certain behavior is ascribed a causal connection to some stimulus. Therefore, it was asked how blessings might have been seen in such a ritual framework and where the magical agency could be located.

In Jesper Sørensen's cognitive theory of magic, the most efficacious ritual would be the one in which a shaman (agent) uses magic tools (object) to perform a strictly prescribed set of actions (action). The theory suggests that magical agencies are often combined, but analytically, these can be separated and investigated as to whether the ritual setting may encourage one type of agency over another. One central textual representation of a ritual in the Dead Sea Scrolls, the covenant renewal ritual in the Qumran Community Rule (1QS) and especially its priestly blessing, was thus analyzed and compared to other texts with blessing activities. In the covenant ritual, the agency was most probably meant to be a combination of different special characteristics that blended the ordinary domain with the sacred. (1) It was agent-based to the extent that only divinely chosen priests could perform the blessing, but the magical agency also lay in the timing of the ritual and in the participants and their ability to participate in the ritual event whole-heartedly, follow the desired order in the covenant movement, and thus receive the blessing for the lot of God. Some other blessings in other texts were clearly not so priestly-centered. (2) The covenant ritual was also action-based to the extent that the words and actions recalled past mythic events, but were also sufficiently flexible to allow adding elements in significant ways. The ancient priestly blessing was seen to extend from the distant past to the present elect ones so that they, despite possible marginalization and distress, were blessing God for his good gifts, which now often were identified as intellectual and immaterial gifts. Some other blessings relied much more on repetitive language and references to other-worldly beings in order to create a special aura for the action. (3) The covenant ritual was also object-based to the extent that purification by water was given special significance or functioned as a locus for receiving efficacious purification as a result of following the correct divine order and blessing God. A perception of contagion is easily triggered in relation to a medium like water.

In the course of the analysis, I have hopefully shown how this analytical tool might be used to illuminate differences and similarities in texts. The priestly blessing is actually quite rare. Instead, there is a general growth of praise-blessings in the Second Temple literature to the extent that humans are seen to have been created for the purpose of praising (Festival prayers 1 Q $34+34$ bis $3 \mathrm{i} 6-7) .{ }^{54} \mathrm{In}$ 1QS 10:10-16, the first person speaker recounts how blessing and praising God characterize every

\footnotetext{
${ }^{54}$ See further Jeremy Penner, Patterns of Daily Prayer in Second Temple Period Judaism, STDJ 104 (Leiden: Brill, 2012); Mika S. Pajunen, "The Praise of God and His Name as the Core of the Second Temple Liturgy," ZAW 127 (2015): 475488.
} 
action he takes. Evidently, there are more texts about pronouncing a curse than a blessing (benediction) on humans, so that even in texts where you would expect benedictions as a counterpart to cursing, the only preserved instances of brk may be about praising God (such as 4QBerakhot). ${ }^{55}$

If blessing action in general is more frequently about humans praising God than humans pronouncing blessings on humans, the question arises as to whether such praise-blessings are ascribed magical or causal efficacy. We may return to the Damascus Document (4Q266): should we conclude that the reason for "expelling a member by blessing/praising God" is that that the praising of God increased to the extent that it replaced the "magical" blessings and curses? This example suggests that praiseblessings were not only symbolic action transmitting information about divine properties or sacred traditions but could have been perceived as action through which one gained the things for which one praised God. The blessing action in the form of praising God was the "new magical skill" ascribing authority to its speaker. ${ }^{56} \mathrm{We}$ might expect that the more such blessings adopted formality, fixity, and rules as is characteristic of ritual actions, the more these rituals were believed to be efficacious.

According to Sørensen, however, there is always a tendency to diminish the efficacy of beliefs, too. There is a universal tension between the intuitive tendency to ascribe ritual efficacy to special aspects of rituals and the tendency to diminish that efficacy and ascribe symbolic meanings to rituals, which often demands reflective thinking. Thus, this tension may also be evinced in the Scrolls: some blessings could have been more receptive to ascriptions of efficacy (blessings tied to infrequent rituals; blessings connected to expected change; repetitive, structured, or carefully timed blessings), and others to reflective symbolic thinking (blessings with little ritual context; blessings that carried information rather than affected a change). Blessings were part of the rich corpus of material for studying and learning what was valued in this movement, but hardly would have survived and flourished without any magical beliefs attached to them.

\footnotetext{
${ }^{55}$ Mika S. Pajunen, "Creation as the Liturgical Nexus of the Blessings and Curses in 4QBerakhot," in Ancient Readers and their Scriptures: Reading the Hebrew Bible and its Versions in Jewish and Christian Antiquity, ed. Garrick Allen and John Dunne (forthcoming), argues that the blessings in 4QBerakhot correspond to the created world order of the creation story - thus again, creation was created to bless, and the curses are a response to those parts of creation that do not participate in the praising.

${ }^{56}$ Furthermore, the general increase of the second person personal address to praise God, instead of the third person form, reflects the tendency to personalize prayer; Chazon, "Looking Back," 155-171.
} 